\title{
The Impact of Sports Course on ITB Student Participation and Enjoyment in Physical and Sporting Activities
}

\author{
Doddy Abdul Karim ${ }^{1, *}$, Yudi Hendrayana², Amung Mamun², Dian Budiana ${ }^{2}$ \\ ${ }^{1}$ Department of Sport Science, Institut Teknologi Bandung, Bandung, Indonesia \\ ${ }^{2}$ Faculty of Sport and Health Education, Universitas Pendidikan Indonesia, Bandung, Indonesia
}

Received May 9, 2021; Revised June 16, 2021; Accepted July 22, 2021

\section{Cite This Paper in the following Citation Styles}

(a): [1] Doddy Abdul Karim, Yudi Hendrayana, Amung Mamun, Dian Budiana, "The Impact of Sports Course on ITB Student Participation and Enjoyment in Physical and Sporting Activities, "International Journal of Human Movement and Sports Sciences, Vol. 9, No. 4A, pp. 82 - 88, 2021. DOI: 10.13189/saj.2021.091314.

(b): Doddy Abdul Karim, Yudi Hendrayana, Amung Mamun, Dian Budiana (2021). The Impact of Sports Course on ITB Student Participation and Enjoyment in Physical and Sporting Activities. International Journal of Human Movement and Sports Sciences, 9(4A), 82 - 88. DOI: 10.13189/saj.2021.091314.

Copyright $\bigcirc 2021$ by authors, all rights reserved. Authors agree that this article remains permanently open access under the terms of the Creative Commons Attribution License 4.0 International License

\begin{abstract}
Objective: The Ministry of Health of Republic of Indonesia (KEMENKES) says that obesity, stress, and degenerative diseases are among the symptoms and impacts of the less participation of Indonesia's youths in doing physical activities. The major goal of the present research is to measure the impact of compulsory sports course on student motivation to take part in sport activities after the course, as well as on the fitness of ITB first-year students. Materials and Methods: The research used a qualitative-descriptive research method. 310 informants were involved in the research. All informants filled in a three-stage questionnaire, including informant identification, informant motivation, and the impact of their involvement in compulsory sports general course (MKU). The data analysis used in the research was statistic-descriptive. Results: The research results showed that $86(57 \%)$ informants said that they had not background in doing sports and $64(43 \%)$ informants said that they routinely did sports. Moreover, the data showed that all informant (150) said that they would do sport activities individually and be motivated by the compulsory sports general course they did at ITB. Conclusion: Based on the questionnaire that we had developed and distributed, the research showed that there were some changes in both motivation and enjoyment in doing sport activities individually after having taken part in compulsory sports course at ITB.
\end{abstract}

Keywords Physical Activities, Questionnaire, Life-Style, Health

\section{Introduction}

Indonesia currently ranks the fourth among the most populous countries with $268,074,600$ people [1]. More specifically, Central Bureau of Statistics (BPS) registers Indonesia's youth by $21,845,100$ people, seen as a hopeful indication that Indonesia will come to be a more advanced and productive country in the future [2]. However, despite of being the fourth largest in population and with a good youth growth expectancy, Indonesia now faces a considerable serious problem, the less physical activities of people, including the youth [3].

Advances in technologies with all their facilitation may be one of the main reasons for the less physical activity of Indonesia's youth [4]. For example, there are so many technological applications that facilitate individuals and groups to go to any place, without doing a lot of physical activities [5]. It results in significant impacts on the decrease of health and fitness of Indonesia's youth generation [6]. Interestingly, KEMENKES said that obesity, stress, and degenerative diseases are among the symptoms and impacts of the less participation of 
Indonesia's youths in doing physical activities. [7]

Bandung Institute of Technology is one of the colleges in West Java Province, Indonesia [8]. It is now offering a Compulsory Sport General Course to all of its first-year students. Some theories and researches reveal the positive impacts of doing sports [9-10]. For example, Romero et.al. [9] suggest that there are physical improvements in young and old women after having performed physical activity of plyometric jump training (PJT). Moreover, there are also some researches that observe the impact of enjoyment from doing sports on physical fitness [11-12]. Specifically, Duberg et.al. [11] show that performing a physical activity of aerobic dance can decrease both stress response level of individuals and psychosomatic level and increase an individual's physical fitness.

Todays, there are so many researches that deal with only the impact of doing a sports activity on an individual's physical improvement and performance [13-15]. Meanwhile, the researches that determine the impact of doing compulsory sport activities on motivation to perform sport or exercise activities after having accomplished the course, being considered as a life requirement and has some impact on an individual's fitness, is rarely found. Therefore, the main purpose of the present research was to measure the impact of compulsory sports general course on motivation to take part in sport activities after the course, as well as on the fitness of ITB first year students. The second purpose of the research was to offer a preliminary description of the effect of compulsory sport activities on motivation to perform sport activities after the course, as well as an initiator for later researches for observing the impact of sports on health.

\section{Research Methods}

\section{Participants}

Three hundred and ten (310) participants were involved in this qualitative-descriptive research. The informants who met the criteria of inclusion in the research were: male and female, registered as an active first-year student at ITB, attending sport general course in first or second semesters, and attending sport general course whose attendance was $80 \%$ in minimum of the total scheduled sessions for one semester. The exclusion criteria from the research were: ITB students who didn't attend sport course in semester one or semester two, has attendance of less than $80 \%$, and got a grade lower than C (D or E) for sport course. All participants were received explanation on instruction and confidentiality of the filling out of the research questionnaire during the last session of compulsory sport course.

\section{Questionnaire}

Every participant received one questionnaire via an android link (Google form) after having finished the last session of the compulsory sport course. The questionnaire consisted of four (4) major sessions of questions. The initial session consisted of six (6) questions, as a stage of informant identification, to determine if the informant met the inclusion or exclusion criteria (the questions can be seen on table 1). Stage two contained four (4) questions related to each informant's background of sport activities, and their own expectation before attending the compulsory sport course (the questions can be seen on Table 2). Then, in third session, there were six (6) questions to fill in, it is related to the impact of attending the compulsory sport course on health and fitness (the questions can be seen on table 3).

At stage four, we presented three (3) questions, related to the impact of motivation to perform sport or exercise after having finished the compulsory sport course (the questions can be seen on table 4). All informant data were then analysed. The data analysis used to determine the impact of the compulsory sport course on motivation to perform sport activities later and the fitness of ITB first-year students was statistical-descriptive.

\section{Informant Data Selection Process}

After the questionnaires were distributed via Google Form link, the researcher allowed one week to every participant who met the criteria to be an informant. After the questionnaire data is collected, then information is obtained, both those that meet the criteria to be sampled and do not meet the requirements to be tested. In this selection (filtering) session, 150 informants who met inclusion criteria were selected, of the total 310 participants. Afterward, the data of the 150 informants were processed, and analysed qualitatively and descriptively.

Table 1. Stage-One questionnaire, containing questions related to the identification of informants

\begin{tabular}{ccc}
\hline No & Questions & Answer Options \\
\hline 1 & Are you ready to fill in this questionnaire? (there is an explanation of the questionnaire) & Yes ; No \\
2 & What is your age now? & 17 years old ; 18 years old; 19 years old \\
3 & In what semester are you now? & Semester $1 ;$ Semester 2 \\
4 & Do you attend compulsory sport course? & Yes ; No \\
5 & If Yes, how many times are your absence for one semester? & $<80 \% ; \geq 80 \%$ \\
6 & What is your grade for the compulsory sport course? (scale A, AB, B, BC, C, D, E) & $\mathrm{A} ; \mathrm{AB} ; \mathrm{B} ; \mathrm{BC} ; \mathrm{C} ; \mathrm{D} ; \mathrm{E}$ \\
\hline
\end{tabular}


Table 2. Stage-two questionnaire, related to each informant's background of sport activities, and their own expectation before attending the compulsory sport course

\begin{tabular}{|c|c|c|}
\hline No & Questions & Answer Options \\
\hline 1 & Do you routinely exercise individually? & Yes; No \\
\hline 2 & $\begin{array}{l}\text { If Yes, how long, and how much is the average time you } \\
\text { take for exercise in a week? }\end{array}$ & $\leq 30$ minutes $; \geq 30$ minutes; others \\
\hline 3 & If No, why don't you exercise? & $\begin{array}{l}\text { My body feels sick from doing sport; Cannot perform sport movements; } \\
\text { Shy to perform sport; No time; Others }\end{array}$ \\
\hline 4 & $\begin{array}{l}\text { Besides from getting a grade, what is your goal of } \\
\text { attending compulsory sport course? }\end{array}$ & Health; got attracted to one sport; just to enrich knowledge; others \\
\hline
\end{tabular}

Table 3. Stage-three questionnaire, related to the impact of attending the compulsory sport course on health and fitness

\begin{tabular}{ccc}
\hline No & Questions & Answer Options \\
\hline 1 & $\begin{array}{c}\text { After having attended compulsory sport MKU, is there a } \\
\text { change in the health quality of your body? }\end{array}$ & Yes ; No \\
2 & If Yes, what do you feel? & My weight becomes more ideal; rarely infected by influenza; Others \\
3 & If yes, explain what do you feel. & Essay form \\
4 & After having attended the compulsory sport course, do you & Yes; No \\
5 & feel more fit? & Able to run $5 \mathrm{~km}$ nonstop; able to perform coordinated movements of \\
6 & If what is the significant evidence of your fitness? & Essay form \\
\hline
\end{tabular}

Table 4. Stage-four questionnaire, related to questions on motivation to do sport activities after having accomplished compulsory sport course

\begin{tabular}{ccc}
\hline No & Questions & Answer Option \\
\hline 1 & $\begin{array}{c}\text { After having accomplished the compulsory sport course, would you still } \\
\text { consistently perform sport activities? }\end{array}$ & Yes; No \\
2 & If yes, what is your reason and motivation? & $\begin{array}{c}\text { Health; to have ideal weight; just for fun; to seek proud } \\
\text { (sensation); others }\end{array}$ \\
3 & If no, what is your reason? & $\begin{array}{c}\text { Feels incompetent to perform sport movements; feels } \\
\text { under pressure; no time; others }\end{array}$ \\
\hline
\end{tabular}

\section{Results}

Based on the research results, the following data were obtained:

\section{Stage-Two Questions}

Did you routinely exercise individually before?
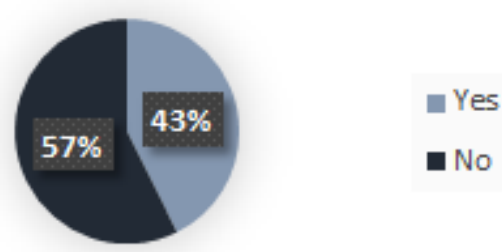

No

Figure 1. Questionnaire on participants' sport background

If Yes, how long, and how much is the average time you take for exercise in a

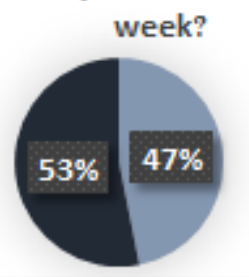

- $<30 \mathrm{~min}$

- $>30 \mathrm{~min}$

Figure 2. Questionnaire on average of doing sport in one week

\section{Besides from receiving a grade, what is your goal in attending compulsory sport course?}

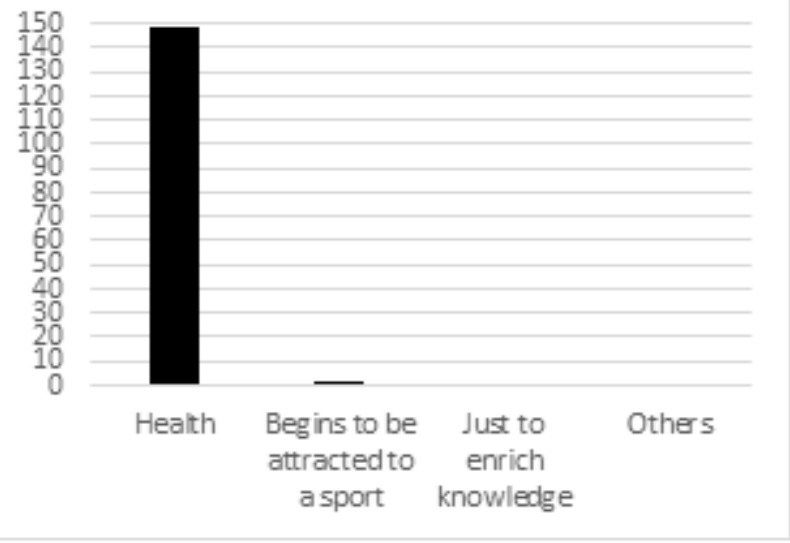

Figure 3. Questionnaire on the goal of attending compulsory sport course

According to Figure 1, the questionnaire data on participants' sport background show that 86 (57\%) informants said that they had no background in performing sport activities; 64 (43\%) informants said that they routinely did sports. In the next session, the questions 
asked respondents who answer "Yes" to state the duration of doing sport activities. Based on Figure 2, from the sample who answered routinely exercising, it was found that the average duration of exercising was $47 \%$ of the 64 participants exercising less than 30 minutes, while $53 \%$ of the others exercised for more than 30 minutes. According to Figure 4, the reason for doing sport shows that respondents who answered "No", 25 informants did not exercised because they felt sick, 30 informants said they could not perform sport movements, 20 informants said that they were shy to perform sports, and 10 informants said that they had no sufficient leisure time. Only 1 informant whose answer was "Others" and gave a tentative reason, i.e., no motivation to do sport. In the stage two, we also obtained data on the informants' motivation or expectation in attending the compulsory sport course, besides from receiving academic grade. Based on the Figure 3, questionnaire on the goal of attending compulsory sport course, 148 informants had a motivation to get health as one of their goals for attending compulsory sport course, while 2 informants said that their motivation to attend compulsory sport MKU was to be more familiar with some sports.

\section{Stage-Three Questions}

In the session-three questions, we showed facts on some questions we had asked the informants. The data we collected are as follows. According Figure 5, the impact compulsory sport course on health for the question "After attended the compulsory sport course, is there change in the health quality of your body?", 148 informants answered "Yes" and 2 informants answered "No". Based on Figure 6, it is found that $99 \%$ of the information felt fit after arriving at the course of the compulsory sport, related to the changes felt by each informant showing that 140 informants answered: "rarely get influenza." According figure 7 questionnaire on the impact of compulsory sport course on health, 6 informants felt that their weight became more ideal resulting from performing compulsory sport course. Another 2 informants answered Others, and filling in essay column, saying that when they waken up, they felt that their body was in better condition (not limp), and rarely sleepy during their normal activity duration in general. For those informants who answered "No", the fact revealed that they did not get a significant impact, because the 2 informants have had a background of good and routine sport activities, so there was no significant change they felt in their body.

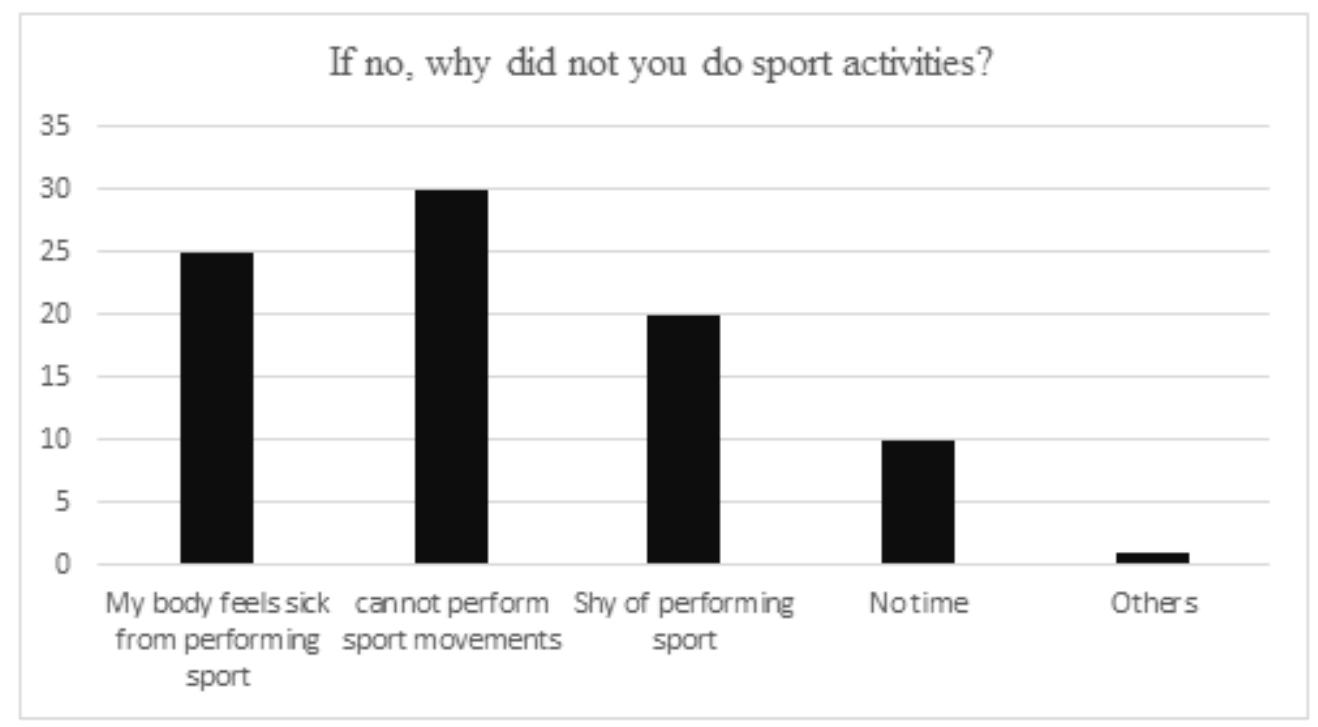

Figure 4. Questionnaire on reason for doing sport 
The same as the prior question related to health context, but now the question in the session three is, "do you felt more fit after having attended compulsory sport course?" To the question, 148 informants said "Yes" and 2 informants said "No". Figure 8 shows the impact of compulsory sport course on fitness of the total 148 informants, 127 informants said that they felt significant impact of fitness such as: able to run for $5 \mathrm{~km}$ nonstop, 13 informants said that they were able to perform coordinated movements of sports better, and 7 informants said that they were able to lift heavier loads. Another 1 informant answered Others, where in the essay form the informant filled in it was said the informant got significant impact on fitness, such as became able to perform lots of light sport activities such as gym, swimming, and basket. On the other side, the 2 informants who answered "No" about the effect of compulsory sport course on fitness said that they did not feel significantly better fitness because they have been highly fit, as they had performed sports before attending the compulsory sport course.

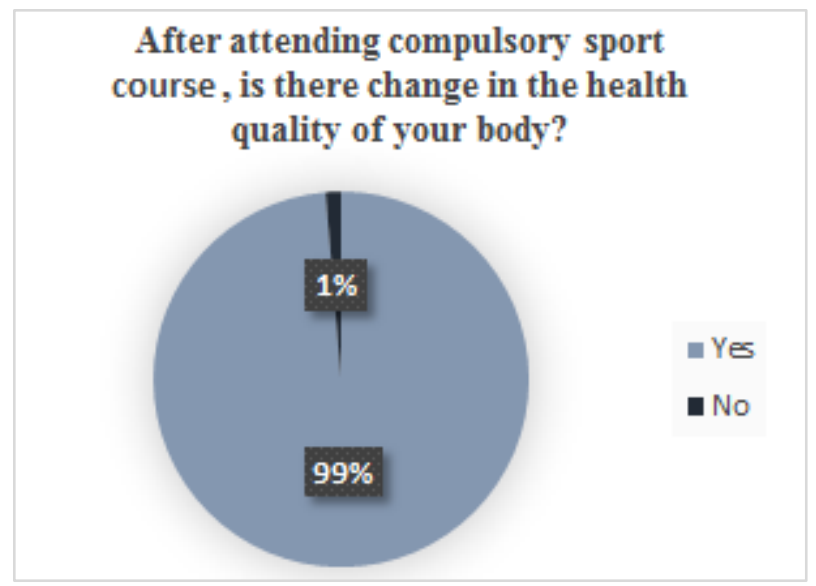

Figure 5. Questionnaire on the impact of compulsory sport course on health

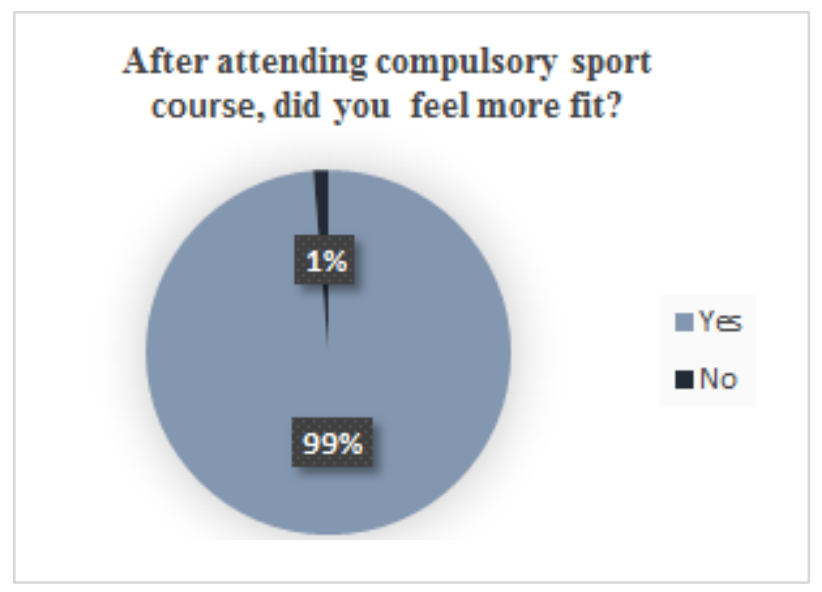

Figure 6. Questionnaire on the impact of compulsory sport course on fitness

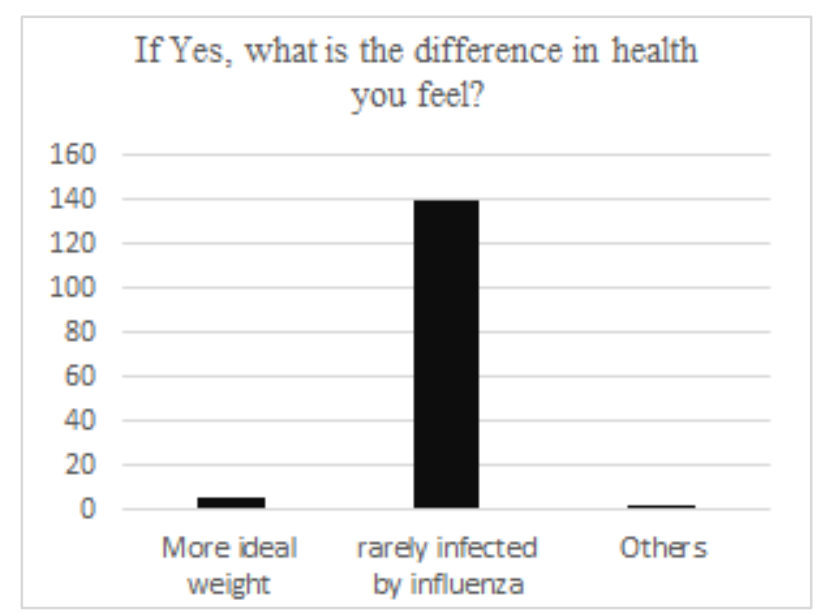

Figure 7. Questionnaire on the impact of compulsory sport course on health

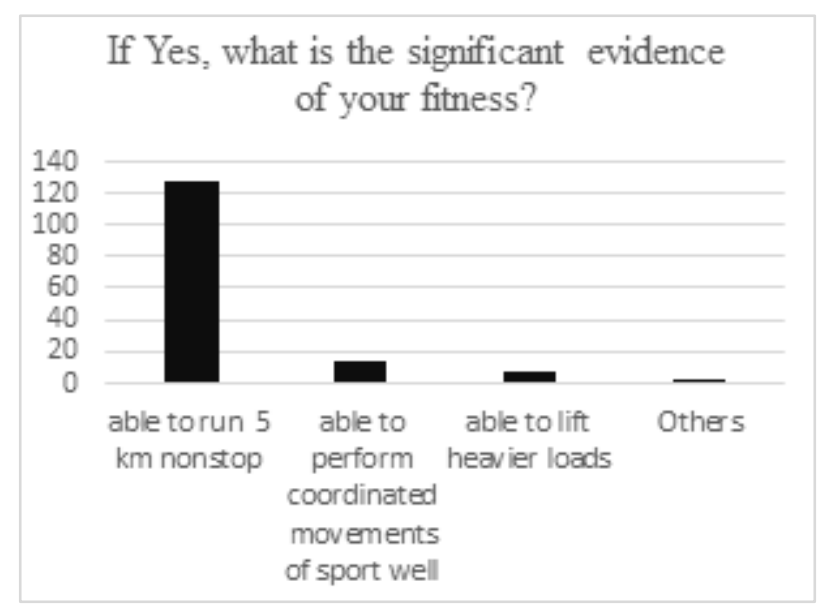

Figure 8. Questionnaire on the impact of compulsory sport course on fitness

\section{Stage-four Question}

In the last session, presented in Figure 9, the intention to do sport individually after having finished the compulsory sport course, we asked several key questions concerning the research goal, to reveal if the compulsory sport course could stimulate a change in the motivation of students to do sport activities individually later. The data we collected showed that 150 informants said that they would do sport activities individually, motivated by the ITB compulsory sport course they had accomplished. Regarding Figure 10, the motivation to do sport individually, we followed up the question by asking a question on what is the motivation of the students if they answered that they would be committed to doing sport activities individually. The data we obtained from the respondents are as follows: 148 informants (99\%) answered that they do sports for health, 1 informant said for ideal weight, and another one said just for fun. 


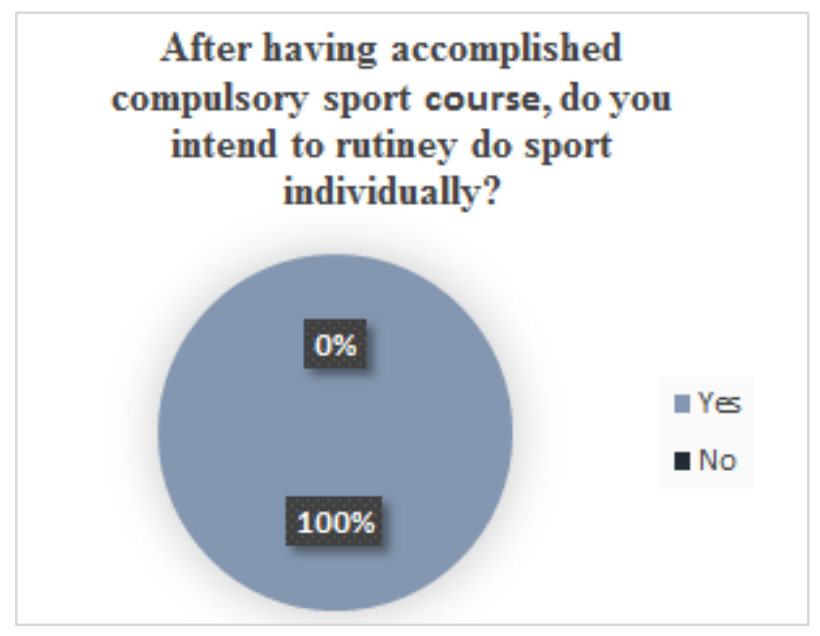

Figure 9. Questionnaire on intention to do sport individually after having finished the compulsory sport course

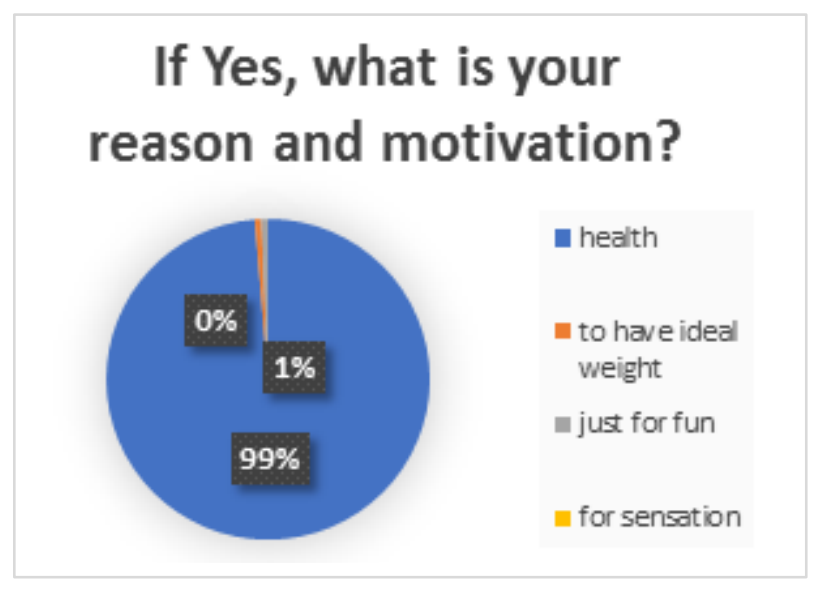

Figure 10. Questionnaire on motivation to do sport individually

\section{Discussion}

The research had multiple goals. The first goal was to know the impact of compulsory sport course on motivation to do sport activities later, and also impact on the fitness of ITB first-year students. Second goal was that the present research might be an initial description about the effect of compulsory sport activities on motivation to do sport later, so that it may become an initiator for next researchers in observing the impact of sport on health. Considering our goals, the research was successful in measuring the impact of compulsory sport course on students' motivation to do sport activities individually later. We also expect that the research result might become a description for next researches in mapping the interest of students in doing sport activities.

Based on the research result, a majority of the informants (57\%) had never had background of performing sport routinely and the remaining percentage $(43 \%)$ said that they were routinely doing sport. This phenomenon is surely in agreement with an earlier research by Leduc et.al. [16] suggesting that student-youths generally practice more irregular life pattern (sleep quality and habit of doing sport activities) than athletes do. Though different in research goal, sample characteristics, and the educational level of sample, our research assumes that the earlier research by Leduc et. al. is also a reflection of the youth's life pattern in general with non-athlete status.

The research result also revealed that there was significant impact on health after the participants had performed compulsory sport course activities. This finding is in agreement with several previous researches concerning the benefits of doing sport on health [17-19]. For example, Warburton et.al. [17] say that it would have impact on better health significantly if an individual can perform sport activities more actively. The physical activities in compulsory sport course also showed an impact on student's fitness. This could be seen from the informants' responses, recognizing that there was change in the fitness of their body. They could run for $5 \mathrm{~km}$ nonstop; their sport coordinated movements got better; and they were able to lift heavier loads than before. These are evidences of the better fitness they felt. Particularly, the result of the present research is in agreement with that of Oja et.al. [20], suggesting that the impact of doing sport activities (exercise) routinely in some sport branches may improve the performance of individuals.

In line with our purpose, to know the impact of compulsory sport course on the motivation and enjoyment in doing sport activities later, we could assume that attending compulsory sport course may enhance the interest in enjoyment of the informants in doing sport later. The research findings actually espouse some researches [21,22]. For example, Giovanna et.al. [22] suggest that inclination to perform sport by employees/workers may reduce stress in working, so they become routinely (addicted) doing sport as one of the activities that may enhance their health, mentally and physically.

The data revealed by the research may expectantly become the stimulation for further researchers, concerning the impact of physical activities applied in an educational curriculum that can affect students' motivation to perform sport activities individually after having accomplished the learning activities in the curriculum. This is important as the main goal of doing sport activities is to get better quality of health and fitness. The researchers are aware that there are some drawbacks to overcome, such as the small number of sample and less reliable questionnaire. Moreover, we encourage next researches to involve more informants who are asked to fill in questionnaire to avoid data bias. Other measuring parameter like questionnaire should be dealt with more deeply related to one's physical activities, and the impact of the physical activities on the change in individual informant's physiology. The researchers also hope that there would be other measurements of physiological parameter, such as measurement of anthropometry (body fat, weight, etc.) that 
may support further researches, to answer unresolved phenomena.

\section{Conclusion}

Based on the questionnaire we developed and distributed, the present research showed that there were changes in both motivation and fun in performing sport activities individually after having accomplished ITB compulsory sport course activities.

\section{Acknowledgement}

The researchers thank ITB staff and all stakeholders involved for their contribution to make the research accomplished well.

\section{REFERENCES}

[1] Chandra S. Mortality from the influenza pandemic of 1918-19 in Indonesia. Popul Stud (Camb). 2013;67(2):185193; doi: 10.1080/00324728.2012.754486.

[2] Badan Pusat Statistik. Statistik Indonesia 2018. 1st ed. Badan Pusat Statistik RI, Jakarta 2018.

[3] Rachmi CN, Li M, Alison BL. Overweight and obesity in Indonesia: Prevalence and risk factors-a literature review. Public Health. 2017;147:20-29; doi: 10.1016/j.puhe.2017.02.002.

[4] Lee J, Piao M, Byun A, Kim J. A Systematic Review and Meta-Analysis of Intervention for Paediatric Obesity Using Mobile Technology. Stud Health Technol Inform. 2016; 225:491-494. PubMed

[5] Latif MZ, Hussain I, Saeed R, Qureshi MA, Maqsood U.Use of Smart Phones and Social Media in Medical Education: Trends, Advantages, Challenges and Barriers. Acta Inform Med. 2019 Jun;27(2):133-138. doi: 10.5455/aim.2019.27.133-138.

[6] Azhari IS, Wilujeng LK. Relationship between physical activity, fitness and body image with obesity among senior high school students at Banda Aceh Municipality. Bul Penelit Sist Kesehat. 12(3):319-329.

[7] Ministry of Health. Data dan Informasi Profile Kesehatan Indonesia. 1st ed. Kemenkes RI, Jakarta 2018.

[8] Institut Teknologi Bandung. Beranda Informasi Publik. Tersedia di link: https://www.itb.ac.id/informasi-publik. Diakses pada tanggal 05 January 2020.

[9] Romero C, Ramirez-Campillo R, Alvarez C, Moran J, Slimani M, Gonzalez J, Banzer WE. Effects of Maturation on Physical Fitness Adaptations to Plyometric Jump Training in Youth Females. J Strength Cond Res. 2019 Jul 31. doi: 10.1519/JSC.0000000000003247

[10] Warburton, D.E.R.; Bredin, S.S.D. Health benefits of physical activity: A systematic review of current systematic reviews. Curr. Opin. Cardiol. 2017, 32, 541-556, doi:10.1097/HCO.0000000000000437.

[11] Duberg A, Hagberg L, Sunvisson H, Möller M. Influencing self-rated health among adolescent girls with dance intervention: a randomized controlled trial. JAMA Pediatr. 2013;167(1):27-31; doi: 10.1001/jamapediatrics.2013.421.

[12] Murphy MH, Blair SN, Murtagh EM. Accumulated versus continuous exercise for health benefit: a review of empirical studies. Sports Med 2009;39:29-43.

[13] Andersen LJ, Hansen PR, Sögard P, et al. Improvement of systolic and diastolic heart function after physical training in sedentary women. Scand J Med Sci Sports 2010;20:50 7.

[14] Khan KM, Thomson AM, Blair SN, et al. Sport and exercise as contributors to the health of nations. Lancet 2012;380:59-64.

[15] Krustrup P, Christensen JF, Randers MB, et al. Muscle adaptations and performance enhancements of soccer training for untrained men. Eur J Appl Physiol 2010c;108:1247-58

[16] Leduc C, Tee J, Weakley J, Ramirez C, Jones B. The Quality, Quantity, and Intra individual Variability of Sleep Among Students and Student-Athletes. Sports Health. 2020 Jan/Feb;12(1):43-50. doi: 10.1177/1941738119887966.

[17] Warburton DER, Bredin SSD. Health Benefits of Physical Activity: A Strengths-Based Approach. J Clin Med. 2019 Nov 21;8(12). pii: E2044. doi: 10.3390/jcm8122044.

[18] Warburton, D.E.; Nicol, C.; Bredin, S.S. Health benefits of physical activity: The evidence. Can. Med. Assoc. J. 2006, 174, 801-809.

[19] Rutten, A.; Abu-Omar, K.; Messing, S.; Weege, M.; Pfeifer, K.; Geidl, W.; Hartung, V. How can the impact of national recommendations for physical activity be increased? Experiences from Germany. Health Res. Policy Syst. 2018, 16, 121, doi:10.1186/s12961-018-0396-8.

[20] Oja P, Titze S, Kokko S, Kujala UM, Heinonen A, Kelly P, Koski P, Foster C. Health benefits of different sport disciplines for adults: systematic review of observational and intervention studies with meta-analysis.Br J Sports Med. 2015 Apr; 49(7):434-40. doi: 10.1136/bjsports-2014-0938 85 .

[21] Dugdill L, Brettle A, Hulme C, McCluskey S, Long AF. Workplace physical activity interventions: A systematic review. International Journal of Workplace Health Management 2008;1(1):20

[22] Calogiuri G, Evensen K, Weydahl A, Andersson K, Patil G, Ihlebæk C, Raanaas RK.Green exercise as a workplace intervention to reduce job stress. Results from a pilot study. Work. 2015;53(1):99-111. doi: 10.3233/WOR-152219. 